\title{
Biedermeier desk in Seattle: the Veit Simon children, class and the transnational in Holocaust history
}

\author{
Anna Hájkováa and Maria von der Heydt ${ }^{\mathrm{b}}$ \\ ${ }^{a}$ Department of History, University of Warwick, Coventry, UK; ${ }^{\mathrm{b}}$ Technical University Berlin, Berlin, Germany
}

\begin{abstract}
This study offers a transnational history of the Holocaust based on a study of a well-known Berlin Jewish family, the Veit Simons. The authors use this tangled family history as a point of departure for a transnational history of the Holocaust. In particular, they show how to read the links connecting the protagonists to the wider world as a means of writing transnational history. Their history also shows the interconnectedness of perpetrators and victims. Moreover, they demonstrate the importance of the category of class for our understanding of the experience of Holocaust history. While the Veit Simons could hold off some of the persecution, eventually the Holocaust brought them to the ground, resulting in a story of illness, death and loss. Finally, the authors read the story from a feminist angle, offering an examination of the interplay of gender, class and persecution, examining how gender played out in coping while losing one's former class.
\end{abstract}

\section{ARTICLE HISTORY}

Received 28 January 2016 Accepted 23 September 2016

\section{KEYWORDS}

Holocaust; Jewish history; gender; sexuality; class; transnational history; German history; women; agency; mixed marriages

How can we write an intimate history of a transnational genocide? Placing the personal horrors meaningfully into the scope of the European genocide is difficult: how to relate each analytical category to another and do them justice? We set out on this mission to advocate for transnational history of the Holocaust. We believe that the study of a well-known Berlin Jewish family, the Veit Simons, offers an excellent point of departure.

General history has embraced transnational history, but Holocaust studies, while acknowledging that the Holocaust was a markedly transnational event, has not engaged with it much. Holocaust histories are mostly limited to the narrow frameworks of national histories: as German, Czech, Polish, or Zionist, Israeli history. ${ }^{1}$ Transnational history is concerned with networks, linkages, connections and interchanges that cut across nation-states and boundaries; it is a way of looking rather than looking at different things, a 'methodic set that defines the endeavor itself.' 2 Transnational history shines a new light on familiar histories by telling us about cultural transfer and hence tangibly different experience. However, much of the Holocaust, particularly the experience of its victims, was pronouncedly transnational: migration and diaspora are paradigmatic examples of transnational history, historical processes which, rather than happening in different places, are constructed in between places. The new societies formed in the ghettos and concentration camps, or the emigrant 
communities in the United States, Mexico or Chinese Harbin - places of new, interwoven cultures and altered habits produced by their transnational nature - are obvious examples of these in-between places. Only when we recognize their transnational nature can we understand the very condition of the victim societies that the Holocaust brought about. ${ }^{3}$

In this article, we pursue the experience in a family scattered and persecuted around Europe as a consequence of the Holocaust. ${ }^{4}$ We concentrate on the individual experience, following Saul Friedländer's argument that the inclusion of an individual victim's voice is the best way to grasp the extraordinariness of mass murder. ${ }^{5}$ We connect the local, family level to the global dimension of the genocide. Including the local is a critical political dimension that is part of transnational history, as opposed to global or world history. Furthermore, the Veit Simons demonstrate the interwoven nature of the Holocaust; the same family had members experience the same events as both perpetrators and as victims. In addition, during the persecution emerged many ties that connected the family to other groups. Such a tangled family history offers a new take on Saul Friedländer's integrated history of the Holocaust - an interpretation that combines the viewpoints of perpetrators, victims and bystanders. ${ }^{6}$ By conjugating the connections the family gained during the war and systematically following the links they lead to, we offer an examination of the transnationality brought about by the Nazi persecution.

The Veit Simons were a wealthy family. Unlike race and gender, class has not received sufficient attention in Holocaust studies beyond the elites in the ghetto population. ${ }^{7}$ It is a well-known fact that the Holocaust impoverished the victims; Raul Hilberg identified expropriation as a key component of the discrimination that led toward destruction. ${ }^{8}$ Material wealth meant far more than just economic capital: house, furniture and art are crucial parts of how we see ourselves, our taste. ${ }^{9}$ How did losing their property and with it their cherished belongings shape the victims and their habitus? Even in popular representation, there are few examples to draw on. The most obvious example is the effete eponymous Ferrara protagonists in Vittorio de Sica's The Garden of the Finzi-Continis. ${ }^{10}$ The film's cataclysmic ending (the family, expelled from their Eden, awaits deportation in a school-turned-collection camp) is historically authentic: even if wealth improved the chances of emigrating, not everyone succeeded, and many of the formerly wealthy Holocaust victims were murdered.

Finally, we read this history from the point of view of gender, offering an examination of the interplay of gender, class and persecution. Feminist Holocaust scholars have shown that for many women, sexual violence was an inherent component of their experience of persecution: violence and power are often expressed in sexualized brutality. ${ }^{11}$ But how did gender play out in coping while losing one's former class? We suggest that during the persecution, women, especially younger ones, could more easily 'shed' their old class and adapt to new surroundings; however, their integration was influenced by their (largely class-produced) habitus. ${ }^{12}$ While women in this story demonstrate striking flexibility while sustaining familial loyalty, the post-war normative society sometimes saw these adaptations as shameful. The Veit Simon women members who lived this history could not record their wartime stories in writing, but they did relate them to relatives - usually other women. ${ }^{13}$ We show the limits and composition of what can be collected and written as a transnational history of the women and men of one family.

This article is unabashedly driven by the drama of the story we are telling: some aspects may be unusual, but the family's story is symptomatic of numerous personal histories of Jews in Central Europe between 1933 and 1950. This article powerfully dramatizes what a family 
is; we examine the strength of familial bonds, the boundaries of familial solidarity and the changes and stability found in generational and gendered roles. ${ }^{14}$ Historians, memoirists and journalists have presented fascinating, detailed longue durée stories of Central European Jewish families interrupted by the genocide. ${ }^{15}$ These accounts are usually written by family members. We join this trend from the outside while adding a few conceptual remarks: how can these histories be written analytically?

This article is based on sources from 13 archives in five countries. It draws on correspondence from 1935-56, including letters between Theresienstadt and Berlin, as well as testimonies, authors' interviews, diaries, state and secret police records, transport lists and reparation files. Every source genre tells a different story, and each family member recounts differing interpretations of the same events. While we endeavour to write the actual history of the Veit Simon family, we are equally interested in the divergent narratives, experiences and subjectivities.

\section{Prehistory: 1911-30}

The Veit Simons were one of the oldest Jewish families in Berlin: they had resided in the city since the seventeenth century, when they were admitted by Elector Frederick William III. ${ }^{16}$ In 1816, Herman Simon married Henriette Veit ${ }^{17}$; after the marriage, the family continued as 'Veit Simons', 'Veit' being an additional family middle name. Their grandson Hermann had four children with his wife, Hedwig Stettiner: Heinrich (1883), Eva (1884), Katharina (Käthe, 1887) and a son who died young. ${ }^{18}$ Related to many eminent Jewish families - including the Geigers, Warburgs and Oppenheims - the family belonged to German-Jewish haute bourgeoisie. The Veit Simons also held shares in the Brothers Veit bank. Hermann read law at the University of Göttingen where he met and became friends with the gentile Hermann Gabriel. Theirs was an unusual friendship, as they did not share the same social background, nor could either expect to gain social capital from their association. The men named each other as legal guardians of their children in case of a premature death. ${ }^{19}$ Hermann Gabriel moved as German consul general to colonial Dutch Batavia. He died in 1897 and his widow Zella returned with her three young children - Irmgard (1889), Helmuth (1892) and Gisela (1891) - to Berlin and bought a large house in Lichterfelde.

Our story begins around 1908, when Heinrich Veit Simon and Irmgard Gabriel fell in love (Figure 1). Their marriage in 1910 had a pronounced class aspect by being part of a trend of wealthy bourgeois Jewish men marrying less affluent gentile women: Heinrich belonged to the upper ranks of non-noble Prussian society, Irmgard to the bourgeoisie. ${ }^{20}$ Irmgard gave birth to six children: Harro (1911), Ruth (1914), Ulla (1915), Rolf (1916), Etta $(1918)^{21}$ and, seven years later, Judith (1925). ${ }^{22}$ Somewhat unusually, neither of the spouses left their religious community after marriage; the children were raised within the reformed Jewish community, and the household was religiously observant. The daughters had bat mitzvahs (introductions to religious maturity), something still progressive at the time. ${ }^{23}$ Etta, the couple's fifth child, had her ceremony with Leo Baeck, the leader of Liberal Judaism and a family friend. Like his ancestors, Heinrich played a key role in Jewish community life: he was on the board of trustees of the Higher Institute for Jewish Studies, an organization co-founded by his grandfather Karl Berthold in 1872.

The Veit Simon family led a grand lifestyle. They owned two cars and employed a maid, a cook and a gardener. ${ }^{24}$ Along with Hedwig, they lived in a Dahlem villa designed by 


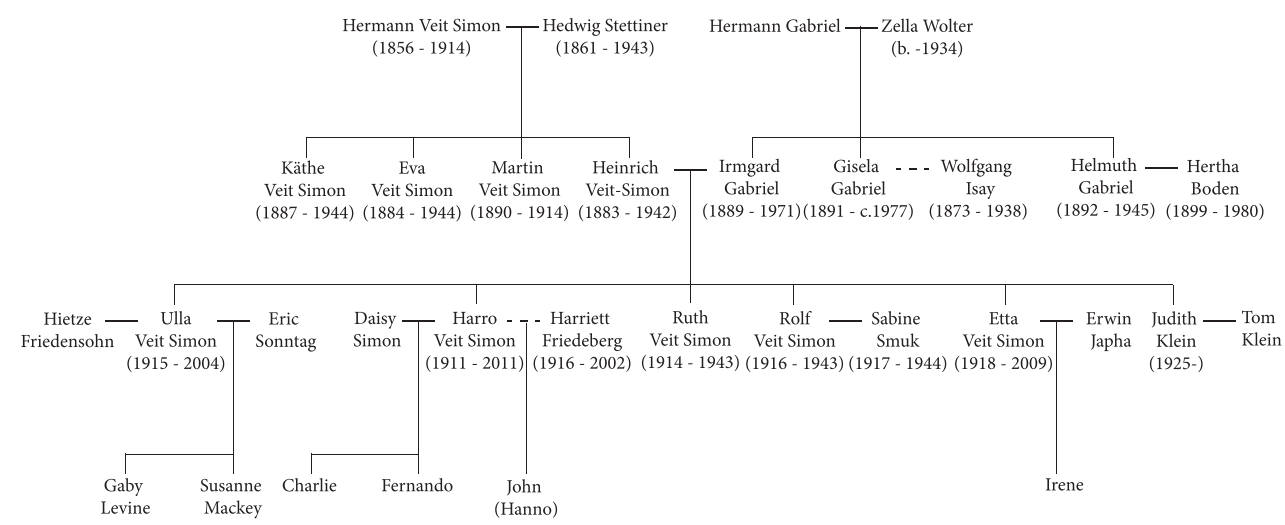

Figure 1. Abbreviated family tree.

Alfred Breslauer, one of Berlin's most popular architects (and the father of the photographer Marianne Breslauer). ${ }^{25}$ In the short years of the Weimar Republic's budding economic recovery in the mid 1920s, Heinrich's law practice in the centre of Berlin became one of the best known in Prussia; his income-tax assessments were amongst the highest in the wealthy district of Dahlem, not sinking below 100,000 Mark. ${ }^{26}$ The law office became even more visible when one of the partners notarized the founding of the Berlin public-transport company. ${ }^{27}$

Heinrich's sisters Käthe and Eva, who were both hearing- and speech-impaired, never married. In 1912, Hermann acquired a plot of land outside Gransee, north of Berlin. Breslauer also designed the estate built there, which was named Katharinenhof, and served as the sisters' home and a fruit plantation; Katharinenhof, with its beautiful countryside and lakes, also served the family as a weekend house. Although Käthe was a trained and keen gardener, the enterprise was only marginally profitable. ${ }^{28}$ Eva, who was a painter, spent long periods in Paris and Rome. ${ }^{29}$

\section{Nazi years: 1930s}

One of the first aspects of the anti-Jewish Nazi persecution was economic targeting: the expropriation of Jewish property which pushed economically struggling Jewish Germans to emigrate ${ }^{30}$ Heinrich's law firm was in the early 1930s still one of Berlin's most respected, having emerged relatively unscathed from two significant blows: the economic downturn of the early 1930s and the first phases of legalized Nazi persecution that barred Jewish lawyers from practising. In 1935, his practice maintained an annual income of over 49,000 Mark. ${ }^{31}$ Such continued prosperity corresponded with a trend described by Frank Bajohr. Bajohr argued that many Jewish businesses responded to National Socialist persecution by working harder, and in doing so they interpreted the consequent temporary stabilization of their businesses as a successful adaption to their new business circumstances - thus causing them to delay or miss the chance to emigrate. ${ }^{32}$

Heinrich was offered a position at the University of St Andrews, but turned it down because he could not bring his mother and sisters. ${ }^{33}$ Like many countries of the time, the United Kingdom did not grant visas to the elderly and disabled. These obstacles forced many families, irrespective of their wealth, to choose between not emigrating or leaving 
their 'undesired' family members behind. ${ }^{34}$ One consequence of such policies was that many families of the disabled Jewish children murdered in euthanasia were living abroad and had been for years. ${ }^{35}$ For Veit Simons, the slow class descent also changed a key marker of class belonging, namely address. ${ }^{36}$ In 1934, the Veit Simons downsized and moved to Irmgard's family house in Lichterfelde. ${ }^{37}$

In 1935, the Reich Citizenship Law, one of the Nuremberg laws, further aggravated the family's situation, and also set the defining groundwork for what was to follow. The Reich Citizenship Law dictated that the offspring of mixed relationships were to be titled Mischling (literally 'mixed breed') and legally set apart from Jews. The law further defined that Mischlinge were to be considered Jewish in three cases: if at or after this date they were members of the Jewish community; if they were married to a Jew; or if they were born to a Jew out of wedlock. ${ }^{38}$ The Mischlinge falling into one of these three categories were referred to as Geltungsjuden. As members of the Jewish community, all six Veit Simon children were Geltungsjuden. Accordingly, they were subject to the persecution all German Jews suffered. The Veit Simon children were open to more state discrimination than their 'fully Jewish' father: Heinrich, as a Jewish man married to a gentile woman, was amongst the individuals in 'mixed marriages' who were protected from the deportations.

The persecution had an immediate impact on the Veit Simon children: the children, who all would have gone on to study, were no longer able to attend university; for those who survived the war, the lack of university education determined years of their later lives and class identity. Like other German Jews, the Veit Simon children started leaving Germany, dispersed over the world..$^{39}$ For the daughters, the way to emigration was more difficult and often linked to marriage. ${ }^{40}$ Harro, the eldest of Heinrich and Irmgard's children, went abroad first. In early 1930 he joined a metals-trading company and was sent to Spanish Bilbao. In 1935, Harro married 18-year-old Harriet Friedeberg, the daughter of a wealthy intermarried family who were family friends; their son Hanno was born in 1936. When Franco's army approached Bilbao in 1938, foreign nationals were evacuated to France. ${ }^{41}$ Due to Harro's adultery, Harriet and Harro's marriage turned sour. Harriet continued to Great Britain, Hanno spent the next year with his grandparents in Lichterfelde, and Harro was posted to Melilla. Heinrich arranged a divorce for the couple, with Harriet maintaining custody of their son. ${ }^{42}$ Harro was dispatched to Chile, to work as manager of a copper mine. In the course of three years, the Nazi persecution, Spanish Civil War and more banal infidelity spread one branch of the family over four countries and three continents.

Ruth, the family's second child, read philosophy at the University of Freiburg, which she soon left, however, following unhappy love affair with a young man considered an unsuitable leftist. ${ }^{43}$ In 1934 the family was still able to send her to study in London for a year and come into the fold. ${ }^{44}$ Upon her return, she trained in graphic design at the Reimann School of Applied Arts, a renowned institution in the Bauhaus and Werkbund Tradition. ${ }^{45}$ She also illustrated Jewish children's books. ${ }^{46}$ Ruth's emigration attempts as a single adult woman were in vain. The American rabbi Jonah Wise offered her an affidavit for emigration to the United States, but the affidavit was never delivered. Wise's failing particularly disappointed Ismar Elbogen, the well-known Berlin rabbi and friend of the family. Elbogen beseeched his acquaintances to assist Ruth, even as he was preparing for his own imminent emigration:

[A] young lady from one of the most distinct Berlin families, herself of great charm, finely educated [...] she speaks and writes fluent English, currently works for one of the largest 
translation offices, and permanently translates crucial documents and legal matters, which she does with great success. Hence you can be sure that [...] she will quickly earn her keep and no one is taking a risky responsibility by sending her an affidavit. ${ }^{47}$

The affidavit never came. Ruth was forced to stay in Germany.

Ulla, Ruth's younger sister, became engaged to her Zionist boyfriend Hans 'Hietze' Friedensohn, who left for Palestine in 1933. But Heinrich would not allow Ulla to leave for Palestine; he and his father were anti-Zionists, and Palestine was in his eyes not a legitimate emigration destination. Instead, Ulla married a friend, Erich Sonntag, the son of a well-known Jewish Berlin physician. ${ }^{48}$ The Sonntags immigrated to England in 1938 following the birth of a daughter. ${ }^{49}$ The second son, Rolf, was everyone's favourite: friendly and good-looking, he was the opposite of the more difficult Harro. ${ }^{50}$ Even Harro's son remembers being told that his mother had been infatuated with Rolf but settled for Harro, who enabled her a way out of Germany, instead. In 1936, Rolf moved to Cologne for work; when his girlfriend immigrated to Chile, Rolf tried in vain to follow her. In October 1938 he was in the Netherlands, effectively stranded. ${ }^{51}$ Etta graduated, in spite of anti-Semitic incidents, from the Gertrauden-Lyceum in 1937 and began an apprenticeship as a graphic designer at the Reimann School. She showed great talent, but had to leave in November 1938 when Jews were excluded from skilled-worker training. ${ }^{52}$

Judith, the youngest, was able to emigrate thanks to her sister's commanding upper-class habitus. Judith began her schooling at the Gertrauden-Lyceum, but in 1937, as anti-Jewish discrimination worsened, she was sent to the Lore Goldschmidt's Jewish school in Dahlem. In December 1938, weeks after Kristallnacht, Ruth enforced Judith's departure at the British Embassy. As a member of haute bourgeoisie, she was accustomed to treating civil servants as subordinates. The clerks, keen to appease the young lady, co-operated. On 30 December 1938, Judith left Germany for Great Britain with a Kindertransport. ${ }^{53}$ It is symptomatic that from two sons and four daughters, two daughters were not able to emigrate; of those two daughters who were able to leave, one emigrated via a marriage, another in a Kindertransport.

In 1938 the Veit Simon family situation took a significant turn for the worse: more family members were expelled from home, the professional and economic persecution radicalized, and the first family member was arrested and physically maltreated. Until 1938, Eva and Käthe lived at Katharinenhof. Following a decree dictating that Jews had to declare their assets, Heinrich, weary of falling property prices, negotiated a hasty sale of Katharinenhof. ${ }^{54}$ Furthermore, in September 1938, Heinrich's licence to practise law was revoked: a heavy blow to the lifelong dedicated and outstanding lawyer. Our profession is part of our selfunderstanding and class belonging, and this blow was only accentuated when Heinrich was allowed to belong to that small fraction of Jewish lawyers who continued as Konsulent, or legal advisers for Jews. ${ }^{55}$ The legal historian Simone Ladwig-Winters stated that it is difficult to estimate a Konsulent's average income. ${ }^{56}$ Heinrich maintained an annual income of 20,000 Marks of scheduled fees; however, he was only allowed to keep a portion of each bill he cashed in. ${ }^{57}$ Further, any income exceeding a certain capped allowance had to be transferred to a compensation board established by the Justice Ministry to support Jewish lawyers banned from practising. Heinrich was careful in financial dealings, so much so that a considerable portion of the family wealth was still accessible in the autumn of 1938 when the family lost possession of their invested property. At that time, Jewish capital assets were frozen, and apart from taxpaying or emigration purposes, the owners were only allowed 
small monthly allowances. ${ }^{58}$ Finally, during Kristallnacht on 9 November 1938, Heinrich was arrested and imprisoned at Sachsenhausen; he was released several weeks later, his health severely damaged. ${ }^{59}$

\section{Holocaust: 1939-42}

The comforts of home notwithstanding, the persecution was closing in on the family. In a poignant marker of the descent in the family's social status, Ruth contracted tuberculosis. The disease made her ineligible to immigrate to Britain, unlike her siblings. ${ }^{60}$ Great Britain demanded a medical check prior to emigration, and TB was on the list of diseases that marked the applicant as undesirable. ${ }^{61}$ In the 1930s, tuberculosis was a wide-spread, often fatal, disease. It was usually associated with working-class and poor living conditions. Since the end of the nineteenth century, it was also seen as a Jewish disease, due to the poor Eastern European Jewish migrants. ${ }^{62}$ In Ruth's contracting tuberculosis, the Veit Simons were put in the same context as the Jews of the Scheunenviertel working-class district.

Yet, the family was still able to send Ruth for treatment in various sanatoriums, corresponding with their social standing: in 1938 in Bad Neuenahr ${ }^{63}$ and in 1940 in Nordrach in Baden and Heidelberg. Ruth could no longer travel easily to treatment in Switzerland; in August 1938, Swiss authorities pressed Germany to introduce a 'J' stamp on Jewish passports, and closely scrutinized German Jews when entering the country. ${ }^{64}$ Moreover, since 1934, the exchange rate of the German Mark had been weak. The 'M.A Rothschild Foundation for Women with Pulmonary Diseases' in Nordrach offered a class-conscious alternative: the sanatorium catered to wealthy Jewish women and was kept according to Orthodox rite.${ }^{65}$ Before the wide use of antibiotics, the usual treatment was isolation, quiet, good nourishment, air treatment and a much-touted new method, pneumothorax (which was thought to enable the lungs to overcome the infection themselves). In July 1939, the Nordrach sanatorium had to join the Reich Association of German Jews, the forced umbrella organization of Jewish life. ${ }^{66}$ During Ruth's stay, the conditions had grown worse; she complained about antisemitism, the vegetarian food, bullying and various prohibitions and the physician's poor bedside manners. ${ }^{67}$ Nordrach cooked vegetarian food because nearly all kosher butchers were forced to close down. ${ }^{68}$ Ruth's complaints also indicate that the formerly fancy sanatorium was no longer solicitous to its patients, and, moreover, that Ruth was not (yet) willing to put up with it.

In late July 1940, Ruth moved to the Thoraxklinik in Heidelberg-Rohrbach, a public hospital founded by the eminent Jewish physician Albert Fraenkel. ${ }^{69}$ The hospital opened in 1931 and was celebrated as a state-of-the-art medical institution with a research focus on TB. Fraenkel was expelled from his position soon after 1933, but the hospital remained open. Ruth was hard pressed to find treatment beyond Jewish hospitals, as waiting periods were long. ${ }^{70}$ Something similar applied to her siblings who usually accompanied her. The sisters had become close friends and Etta started taking over in practical matters. ${ }^{71}$ When her parents suggested Ruth go to Austrian Zell am See, Etta pointed out that she had to stay in a Jewish hotel, of which there were none. ${ }^{72}$ This exchange about accommodation demonstrates the family's class descent. It also shows how Etta was becoming accustomed to the new cumbersome living conditions of the German Jews, unlike her parents. In Nordrach, patients were exchanging notes where they could go; Ruth heard that a friend 'was able to 
stay at the B\&B Reichspost in Heidelberg in spite of the Kennkarte' [the ID was stamped with J]. ${ }^{73}$ It is remarkable that as late as the summer of 1940, Ruth was allowed treatment in Heidelberg; it is possible her half-Jewish ancestry played a role. She was operated on for pneumothorax, which seems to have improved her condition although the operation was painful and left scars. However, she was still ill and returned back to Berlin. ${ }^{74}$

In contrast, for their gentile uncle, Helmuth Gabriel, the year following 1933 was a period of both professional and social ascent. Helmuth joined the NSDAP after May 1933 and worked at the Superior Court of Justice in Celle. ${ }^{75}$ Although he was trained in early 1920s at the office of Maximilian Kempner and Albert Pinner, two eminent Jewish figures of the Weimar legal profession, Helmuth developed anti-Semitic views. In spite of praise as an eminently talented lawyer - one of his evaluations described him as 'material to be transferred to Berlin"76 - Helmuth avoided the capital possibly because he did not want to live in the same city as his Jewish relatives. He refused to shake hands with his brother-inlaw Heinrich at his mother's funeral in 1934, and afterwards severed family ties. ${ }^{77}$ In 1937 he acquired the position of General State Attorney in Hamm (his Catholic predecessor was considered unreliable); the court was known as a grouping of anti-Communist hardliners. ${ }^{78}$ As a state employee, he earned 9,200 RM per annum, much less than his brother-in-law. ${ }^{79}$ In October 1938, Gabriel was appointed to oversee the restructuring of the state's attorneys when the Sudetengau was being merged into the German Reich. In April 1939, Helmuth was named Senior Prosecutor at the German appellate court ${ }^{80}$ and, half a year later, he rose to the position of General State Attorney for the Protectorate Bohemia and Moravia. ${ }^{81}$

Helmuth's life in Prague was like that of other high-ranking occupation administrators, with good pay and excellent housing. Having just turned 40, he used this promotion to marry. With his wife Hertha, he moved from a first apartment in a modernist central building to a six-bedroom villa in Prague-Hanspaulka. ${ }^{82}$ Both addresses had Jewish owners and inhabitants; the first was even designed by the architect Otto Zucker, the later deputy Elder of the Jews in Theresienstadt. With large gardens, wide streets and spacious villas, the second address in Hanspaulka was among the finest residential areas in the city. Between 1939 and 1945, the districts of Střešovice, Dejvice, Trója and Hanspaulka became an area with new German inhabitants. The Aryanized Jewish property fell into the hands of the Emigration Fonds of the Central Office for Jewish Emigration, which then handed out housing to the thousands of new inhabitants in Prague. ${ }^{83}$ By January 1943 Helmuth was eager to return to Hamm, but the war brought about personnel shortages. ${ }^{84}$ As a result, his responsibilities grew. According to post-war documentation, Gabriel oversaw all instances of capital punishment in the Protectorate. ${ }^{85} \mathrm{He}$ also apparently participated in the martial law after the Heydrich assassination, when the German occupiers executed hundreds of Czech intellectuals and razed to the ground the villages of Lidice and Ležáky, killing the men and children and deporting the women to Ravensbrück camp. Later, Helmuth arranged death penalties for Czech forced labourers absent from their draft in Germany. ${ }^{86}$

Until April 1942, Irmgard's and Heinrich's lives did not change greatly. They still lived in a happy marriage. Their living quarters in Lichterfelde were more crowded; the two apartments housed eight adults: Heinrich and Irmgard, Ruth and Etta, Eva and Käthe, Hedwig, and Irmgard's sister Gisela (the official proprietor). In the summer of 1940, the spouses could still enjoy a holiday in Wiesbaden. Around this time, the family met Harald Poelchau, the priest in the Plötzensee prison. One of his wards was Werner Klatt, a 39-year old Mischling journalist. Klatt asked Poelchau, knowing he would be sentenced to death, 
to act as a go-between to his friend Etta. ${ }^{87}$ This friendship with Poelchau would prove important for Irmgard in the following years. In September 1941, Klatt was executed in the prison Brandenburg-Görden. ${ }^{88}$ In April 1941, the Labour Office sent Etta to the Zeiß-Ikon Görzwerke camp in nearby Schönow. She worked 12-hour shifts as a machine operator in the Jewish workforce barrack. ${ }^{89}$

In September 1941, German Jews - including Heinrich, Ruth and Etta - had to start wearing the Star of David. One month later the systematic deportations of German Jews began. It was only by June 1942 when single Geltungsjuden were to be deported to Theresienstadt rather than 'the East', and so in the early months of deportations a large, still unknown, number of them were deported. ${ }^{90}$ While their father was protected from deportation through his mixed marriage, Etta and Ruth were in danger. Heinrich developed an escape plan for them: he purchased false papers with the help of a colleague from Zeiß-Ikon identifying the sisters as Belgian forced labourers. Ruth and Etta were to join a group of women leaving Berlin for furlough to Belgium and from there go to France and then neutral Spain. ${ }^{91}$ Many Holocaust escapes depended on paid help ${ }^{92}$, which ranged widely and also changed over time. In 1939 the working-class Leipziger Dora W., charged 300 Mark $^{93}$; in 1943, smugglers who brought 'illegal' Jews to Switzerland charged between 7000 and 12,000 Mark.

On the morning of 18 April 1942, Etta said farewell to her last gentile friend and went to Berlin's Anhalter train station. However, the escape plan fell through: a Görzwerk colleague who was spiteful at not being included in the escape betrayed the plan to the Gestapo. Etta got out of the subway on Potsdamer Platz only to realize 'the whole place was crawling with the Gestapo; you could recognize them on their trenchcoats. ${ }^{\text {'94 }}$ She was arrested during the ensuing raid. Etta was able to warn Ruth as they passed each other. Heinrich was arrested a few days later. The Gestapo brought both father and daughter to the police headquarters prison at Alexanderplatz. ${ }^{95}$ Heinrich's class habitus shaped his decision for his daughters' escape plan; in being caught, this act of resistance negated the tremulous protection he had as spouse in a mixed marriage. The world and class he came from had no validity in the Gestapo prison.

Heinrich, whom Poelchau described as 'a small, gentle, aristocratic man', had little chance. ${ }^{96} \mathrm{He}$ was beaten to death on 18 May $1942 .{ }^{97}$ Opening her mail the next day, Irmgard found a scribbled note in pencil stating that 'your husband Heinrich Israel Simon has died in the prison Alexanderplatz pol-headq. The corpse is in the morgue. ${ }^{98}$ She was not allowed to open the coffin; she buried her husband at the family lot in the Jewish cemetery at Schönhauser Allee. Heinrich is the last family member to be buried there.

In contrast to her father, Etta's presence of mind in the following weeks demonstrates the young woman's agency in harrowing circumstances. In 1999, she recounted her experience in the police headquarters. She remembered one of her arresting officers looking 'bad', while the other was 'good'. Realizing she was hungry, Etta took out two hard-boiled eggs she had as travel fare, and proceeded to break, peel and devour the snack. ${ }^{99}$ She went on to point out how as a young, attractive woman with good manners she was able to work the 'soft spot' that the 'good' Gestapo man had for her. To protect her, he waited until her father's death so that she could be sent to Theresienstadt, rather than to Riga. The German authorities described Theresienstadt as an advantage camp and a final destination; Riga was a far deadlier place. ${ }^{100}$

Etta framed the horrific experience at the Gestapo as adventure: by impishly eating an egg, signalling that she was not afraid, or treating the Gestapo men with the charm of an attractive woman who knows she will receive aid. As a haute bourgeois woman, Etta was 
familiar with treating clerks and civil servants as subordinates; her habitus shaped her interaction with the Gestapo men. Moreover, in the previous years she had learnt practicality and resourcefulness. Etta continued in her role as family supporter during her imprisonment at the Alexanderplatz prison, where she was housed in a crowded cell with sex workers and petty criminals. ${ }^{101}$ In a letter home, Etta tried to cheer her mother up and frame her imprisonment as an anecdote, downplaying the severity of her condition:

I myself am fine, I am healthy and at peace. I think a lot and lot of you and wish you with all my heart that you stay healthy and that you, with confidence in God, can get accustomed to the situation. Here I tell the others so much about you, father, the siblings and my childhood, that everyone is familiar with all of us and often they have to laugh. ${ }^{102}$

The letter was probably passed by a censor, making mentioning of the horrible conditions impossible. Still, Etta's remark about how she made her fellow inmates laugh, like the egg snack, was an instance of caring for her mother, a reversal of the parenting relationship that was to continue from now on. The remark was also a moment of chutzpa, an assertion of self. Etta's narrative strategy of the persecution as adventure allowed her to exaggerate the control she had. Saul Friedländer pointed out that powerlessness was a key experience for victims in the Holocaust; most of those who bore witness addressed powerlessness in one way or another. ${ }^{103}$ This narrative plot of exaggerating agency and persecution as an adventure was a coping mechanism for young, courageous Holocaust victims who were unaccompanied by parents. ${ }^{104}$

In early July, Etta was transferred to the collection camp for Jews at the Große Hamburger Straße. Leo Baeck, dispatched by Irmgard, visited Etta and sat with her in silence: there was nothing he could do, apart from be present. ${ }^{105}$ The departure from Berlin signified the end of protection of home and the old networks. Ruth's health had drastically deteriorated and she was transferred to the Jewish hospital in the Iranische Straße, the only place she could be treated. However, she chose to join Etta on the transport to Theresienstadt. The two young women were a striking exception on the transport of 7 July 1942: the deportations of German Jews to the Theresienstadt ghetto had just started and at this point included almost exclusively elderly Jews. On this transport of 100 people, $86 \%$ were born before 1880 . The only young people deported at this point to Theresienstadt were Geltungsjuden, whose deportation was retributive. ${ }^{106}$ Similarly, the working-class Geltungsjuden Arnold, Eva and Elly Munter were deported to Theresienstadt on suspicion of Arnold's resistance. ${ }^{107}$ Three years later, at liberation, Etta was one of four survivors from her transport.

On 4 October 1942, Hedwig with her daughters Eva and Käthe were deported to Theresienstadt, carrying away Irmgard's remaining Jewish family. Poelchau related it in an anecdote that would be sentimental if not so poignant in its brevity: Veit Simons had a Persian cat, and whoever came was to admire and pet the pretty animal. ${ }^{108}$ But in February 1942, Jewish households were prohibited from keeping any house animals, and by May, the rule was being enforced. ${ }^{109}$ One day, Irmgard, dealing with the arrest of her daughter and husband, found a letter in the mail threatening denunciation unless the cat be given up. Only days later, Heinrich was killed and the head of household was no longer Jewish - and so, as in Poelchau's title, the cat might live. ${ }^{110}$ The Persian cat, beautiful, costly and immensely impractical, was a memento of the family's elegant life in Berlin with Irmgard. 


\section{Holocaust: in the camps}

The next three years, 1942-45, brought the three Veit Simon children in continental Europe into forcedly transnational communities in concentration camps and ghettos. In the Netherlands, Rolf was part of the new German Jewish emigré culture. To German and Austrian emigrants the Dutch often came across as aloof, so, not welcome by the Dutch majority, the emigrants built their own society. ${ }^{111}$ Their circles were as much new as they were a continuation of the place they came from: old class did not weigh as much. The transnationality of the emigrant society dictated, alongside falling class boundaries, new cultural links and hence engendered a new hybrid national identity. For instance, Anne Frank spoke Dutch rather than German, while her parents often spoke German; she never received Dutch citizenship, and most of her friends were other German emigrants. ${ }^{112}$

Like his brother Harro, Rolf worked for a metal company, Oxyde. ${ }^{113}$ In May 1940, the Netherlands were occupied. In June 1941, following a raid by German security police (SiPo), Rolf was sent to the Schoorl camp along with 310 other young Jewish male hostages. ${ }^{114} \mathrm{He}$ was one of only two prisoners released on account of their mixed background; all others were murdered in Buchenwald and Mauthausen in an attempt to exert SiPo control over the Dutch Jewry. ${ }^{115}$ The remaining Jewish prisoners were organized into the newly founded Dutch Jewish Council. Rolf was hired by the Council in the autumn of 1941 . He was among several thousand clerks working for the Jewish council in the Netherlands. ${ }^{116}$

Even in these dire circumstances Rolf continued to charm people. In October 1942, a 15-year-old acquaintance, Ellen Schwarzschild, remarked in her diary: 'This noon we received a visit from Rolf Simon and his wife Sabine. If I hadn't thought him nice so far, then today I totally think he is cute, and for the first time also good-looking. It's really too bad that he is married.' ${ }^{117}$ In June 1942 Rolf had married the fellow emigrant Zionist Sabine Smuk. Her family were Orthodox merchants originally from Western Ukraine who had settled in Essen. Sabine left for Palestine in the 1930s, where she attended the Agricultural School Nahalal. She later left Palestine for the Netherlands. ${ }^{118}$ Before 1933, Rolf and Sabine would probably never have met, let alone fall in love; their socio-economic, religious and ideological backgrounds were too different. ${ }^{119}$ These previously different characteristics lost their importance, due not only to the persecution, but also due to the transnational nature of their emigrant world. Sabine held a Palestine certificate and thus was to be considered for exchange for Palestine; Germany was trying to exchange Jews with valid certificates for immigration to Mandate Palestine for German citizens in Allied hands. ${ }^{120}$ Yet in marrying Sabine, Rolf weakened his status as a Geltungsjude, even if as clerks for the Jewish Council, Rolf and Sabine were protected pending further notice. At the Jewish Council, Rolf's employment file card stated: 'impression: hardworking' and Sabine's 'very hardworking. ${ }^{121}$ The couple lived with Sabine's little sister Mirjam, whose parents had been sent to the Netherlands after Kristallnacht.

In June 1943, after the Germans arrested a large portion of the Jewish Council, the little family was deported to Westerbork. While at Westerbork Rolf held a post in the Security Service, assisting at the departing transports; Sabine worked as a nurse. ${ }^{122}$ Mirjam was eligible for deportation to Theresienstadt because her parents were already there and she was under 14 years of age ${ }^{123}$, and left Westerbork in September. On a regular basis, transports left Westerbork for annihilation camps; because the camp population was fairly small, most prisoners soon fell victim to deportation. Only prisoners with excellent networks 
or otherwise good protection managed to avoid being deported. Sabine and Rolf, trying to escape their looming deportation, lobbied to have prioritized status on an exchange transport for Palestine via Bergen-Belsen, even hoping (unrealistically) they could include Sabine's parents in Theresienstadt. ${ }^{124}$ The couple could have 'qualified' for Theresienstadt as 'deserved employees' of the Jewish Council and the Westerbork administration. In addition, Rolf begged his mother to reach out to Helmuth, hoping his uncle could help him. Irmgard was not pleased; she commented 'Imagine this!' on the request. ${ }^{125}$ We do not know whether Irmgard wrote to Helmuth, or whether Helmuth did anything.

After avoiding 10 transports to 'the East', the couple was deported to Auschwitz on 16 November 1943. ${ }^{126}$ The seminal Westerbork diarist Philip Mechanicus recorded that the individuals included in this transport were people arrested in hiding, those without transport protection, young people turned down for the Palestine exchange, hospital staff and the patients. It was 'a normal transport, which left with the young men and women singing as they departed'. 27 The couples' traces end in Auschwitz: Sabine was murdered immediately in the gas chamber. ${ }^{128}$ Rolf survived the selection and lived for at least another two months. ${ }^{129}$

For Etta, hitting rock bottom in Theresienstadt meant the final break from her old world. Arriving in Theresienstadt in July 1942, Etta and Ruth experienced a pronounced invalidation of their class background. In summer 1942, the place was at its worst. Theresienstadt was opened in November 1941 and operated as a transit ghetto ${ }^{130}$ meant to receive all Czech Jews and select groups of German, Austrian, Dutch, Danish, Slovak and Hungarian Jews, sending inmates to the killing centres further East. The young Czech Jews, veterans of the ghetto, were handled as the social elite in Theresienstadt, whereas the German and Austrian Jews, often older people, were seen as 'foreigners', and placed on the bottom of the social hierarchy. ${ }^{131}$ The SS installed a Jewish administration to run the ghetto. In the summer of 1942 the Jewish functionaries were overwhelmed by the tens of thousands of new, often very old people from the arriving German and Austrian transports. These arrivals were accommodated in attics, which were empty because they were previously considered uninhabitable.

Thirty years later, Etta described the experience of Theresienstadt as 'permanent rape.' ${ }^{132}$ In the first year, she contracted dysentery, typhoid, scarlet fever, jaundice and heart weakness, and lost 15 kilograms. ${ }^{133}$ For many of the newly arrived, becoming ill was a coping mechanism when things became too difficult; this crisis could be caused by the extreme class descent of arriving in the ghetto. ${ }^{134}$ Even today, being ill is a socially acceptable way of putting aside responsibility. In the ghetto, the overwhelming experience of powerlessness bred by the dirt, hunger and injustice could be temporarily put on hold when ill. ${ }^{135}$ Etta's missing letters for the period of illness - she, always so articulate - represent a narrative gap caused by loss of control.

The arrival of the grandmother and aunts in October 1942 brought back Etta's agency: her relatives needed her help. Conditions in Theresienstadt for the elderly were appalling; an overwhelming majority of the elderly died of starvation-related diseases. ${ }^{136}$ The fact that Hedwig, a frail 81-year old woman, was able to live there for the comparably long time of six months before dying in April 1943, indicates that Etta must have taken care of her grandmother. Käthe and Eva lived in Theresienstadt, working in the sewing room until their deportation in May 1944. Around this time, their old home, Katharinenhof, changed hands again when Rudolf Nadolny, a former Wilhelmine and Weimar diplomat, bought it as his old-age residence. ${ }^{137}$ In autumn 1942, Etta received a summons for a transport. She 
immediately contacted the Jewish administration, citing her and Ruth's exception status as Geltungsjuden, successfully securing their transport protection until autumn $1944 .{ }^{138}$ Three months after arrival, Etta was already well informed about the infrastructure and could negotiate a critical resource.

In spring 1943, Theresienstadt had 44,000 inhabitants: ${ }^{139}$ the forced new prisoner society was large, heterogeneous, asymmetrical and markedly transnational. Theresienstadt erased most of the old class and created new socio-economic hierarchies, based on time of arrival, ethnicity and habitus, social capital and age. A transnational feature of the ghetto was that the prisoner society engendered an interconnected culture, in which familiar things gained a new meaning: being a young attractive German woman meant something else than it did back home. The social inequalities between the veteran Czech and 'foreign' Jews often manifested in sexual relationships: most of the younger non-Czech women survivors remembered cat-calling, even being treated as fair game. ${ }^{140}$

In her Theresienstadt integration, Etta demonstrated her ability to adapt while maintaining a portion of her old class habitus. Etta's job as a lettering artist in the Graphic workshop, part of the Technical department, aided her integration into Theresienstadt. She designed posters and official papers for the Jewish self-administration. She made friends with her colleagues, including her boss, the well-known painter Tomáš Fritta. By spring 1943 she was part of the wealthy in the ghetto: she was smoking ${ }^{141}$, which in Theresienstadt was 'expensive. The SS prohibited smoking to drive up the price of cigarettes, which they were providing to intermediaries, on the ghetto black market. When Hedwig died, Etta followed the custom and claimed her grandmother's wedding ring. 'I sold it for fifty cigarettes', she remarked 40 years later. ${ }^{142}$ Etta also fell in love with Bedřich (Fritz) Lerner, an engineer from Brno, who acted in the ghetto theatre. Fritz was, in fact, married. His wife Ilse was arrested in Brno and sent to Auschwitz; he did not know she perished in October 1942. ${ }^{143}$ To her mother, Etta announced Fritz as an engagement. News of the relationship travelled through Irmgard and reached Rolf in Westerbork and Ulla in London. ${ }^{144}$

Etta's network included people of various ethnicities and former class backgrounds. These transnational Theresienstadt networks gave birth to various selves. To her colleagues, she was a loyal part of the collective, poking fun and drawing little pictures as gifts. She moved into her boyfriend's kumbál - in Theresienstadt slang, a self-timbered room of one's own defining for the social elite. ${ }^{145}$ Lerner's first language was German (he came from chiefly German-speaking Brno); therefore, unlike other German or Austrian women prisoners dating Czech Jews, Etta learnt only a little Czech. She was a friend of, and gave assistance to, her parents' Berlin friends, including the Smuks and later their daughter Mirjam. In the letters to her mother, she presented herself as the old Berlin daughter. She also continued as an educated, high-spirited young German woman. She joined Philipp Manes' productions of staged readings that catered to a predominantly older and formerly bourgeois audience, perhaps the strongest link to the world she came from. When Fritz suggested Etta for Roxanne in Cyranno de Bergerac, Manes was smitten: 'This pretty, young, distinctive creature, offspring of the old, respectable Berlin family, precious and a good speaker. Heard, saw, conquered. Please, I said, rehearse.'146

During this time Ruth was in the TB unit of the Theresienstadt hospital, the last in the string of hospitals of various standing and location where the illness brought her. Medicine in the ghetto embodied a similar new, transnational society. Ruth was being taken care of by one of the leading Czech experts on the disease, František Löwit, the chief pulmonary 
doctor of the Czechoslovak railways. ${ }^{147}$ Divorced by his gentile wife and separated from his teenaged daughter, Löwit was remembered as a dedicated, outstanding physician. By 1943, the medical care in Terezín was, in comparison to other places, excellent. ${ }^{148}$ As most of the elderly had succumbed to diseases caused by malnutrition, after October $1943 \mathrm{~TB}$ and pneumonia became main causes of death among the prisoners. ${ }^{149}$ Löwit and his team successfully healed some of those suffering from TB, and many of the young and childless who were deported to Auschwitz survived. ${ }^{150}$ Ruth, however, grew worse. Thus confirming the above trend. She died on 26 July 1943. Irmgard was hard hit by the news in Berlin. She wrote to Etta: 'What can I tell you, Ettchen! [...] How much happiness must I have possessed to bear so much sorrow! Only the child did not have very much of joy on this earth. Could I not have gone in her stead?'151

The enforced Theresienstadt prisoners' world was made by, and depended on, the SS. In September 1944, most Terezín prisoners believed things were going well: the summer was hot and the cultural productions were at their peak. When the Czech film company Aktualita was shooting a scene in the swimming pool for the propaganda film Theresienstadt: A Documentary Film from a Jewish Settlement Area, Etta and Fritz were cast to join as a good-looking couple. Three weeks later the SS organized a series of devastating transports that carried two-thirds of the inmates to Auschwitz. Almost all of Etta's entire social circle was deported: Fritz, Manes, the Smuks and nearly everyone from the Graphic Workshop. Etta, who could prove that she corresponded regularly with her gentile mother in Berlin, was spared.

\section{Irmgard in Berlin: 1942-45}

During this time, what remained of interfamilial contact lay in Lichterfelde. Irmgard received her children's letters and related the news to her offspring elsewhere. But the persecution carried a toll, and Irmgard became increasingly susceptible to stress. Her relationship to her sisters-in-law became fraught. As her handicapped sisters-in-law waited for their deportation summonses, Irmgard asked Käthe to acknowledge and repay the loan Heinrich issued her in the 1920s for Katharinenhof. ${ }^{152}$ Irmgard felt separated even from her sister Gisela; Irmgard complained to Etta that Gisela did not grasp Irmgard's suffering. ${ }^{153}$ Unlike most other mixed families separated by persecution, Irmgard's correspondence to Etta concentrated on her own problems. ${ }^{154}$ In another Berlin family, Elsa Chotzen and her Geltungsjude son Eppi tried in their letters to capture a normal everyday, and stressed that they were fine. ${ }^{155}$ Elsa spent all her time organizing food to support her three sons and their wives deported to Theresienstadt, sending margarine, bread, lard, sugar, canned food, zwieback, sausage, even clothing. ${ }^{156}$ Irmgard sent parcels with fruit she grew in the garden, tomatoes, summer apples, cleaning detergents and jars with sauerkraut, jam and cooked leeks: things that break or spoil quickly, even though mail usually arrived within one week. The content of Irmgard's packages showed her impracticality, reflecting a trace of her upper-class background: she had no grasp of the durability of food or what could be of most use to a hungry person.

At the same time, however, Irmgard participated in resistance, assisting Jews in hiding and sheltering people - Jews as well as escaped forced labourers - for short periods. To this end, she spent all of her independent funds and Heinrich's life-insurance policy. ${ }^{157}$ We do not know with whom specifically Irmgard worked. She had grown close to the Quakers, and 
was connected to Harald Poelchau as well as the Confessing Church in Dahlem; all three helped Jews in hiding. In spite of our exhaustive research, no one had ever heard about Irmgard Veit Simon. ${ }^{158}$ Irmgard never mentioned persons other than Poelchau, and she was her own sole witness of her resistance activity. It seems that Irmgard's strict keeping of the rules of conspiracy, her sex and the fact that she left Berlin immediately after the war led to her absence in the records. This lack of written record is really the crux of the matter when thinking about issues of women in history. ${ }^{159}$ Today, one finds Irmgard in the footnotes of the work of Jewish male genealogists, thanking her for the materials she provided about her husband's famous ancestors. ${ }^{160}$

\section{The post-war}

The arrival of the Red Army brought a violent end of the war to the Gabriel siblings. For many gentile Germans, the brutality that followed erased most of their class identity, similar to the experience of German Jews a few years previous. Helmuth was arrested during the Prague Uprising. The Soviets sent him to the Bautzen special camp, following a NKVD order to arrest all high-ranking Nazi functionaries. He was likely to stand trial, but died on 22 August 1945 as consequence of the poor conditions. ${ }^{161}$ The last days of war in Lichterfelde were also brutal. Several SS men hid in the Veit Simon family house, where Irmgard was harbouring an escaped Soviet POW. This man eventually persuaded the conquering Red Army soldiers not to kill the inhabitants. Later, Irmgard was sexually assaulted by the Soviet soldiers. ${ }^{162}$ Rape was a collective experience for many German Jewish women and camp survivors at the end of the war. ${ }^{163}$ Irmgard talked about this gendered impact of liberation only with her daughters.

After liberation, the transnational community of Theresienstadt started crumbling as the liberated inmates were repatriated or left for the Deggendorf DP camp in Bavaria. Etta continued working for the Jewish self-administration ${ }^{164}$; her boss from the Technical department, Jiří Vogel, was in charge of the ghetto phase-out, which lasted until the end of August 1945. All of Etta's loved ones were dead. In addition to her family, Fritz Lerner was shot during a death march in January 1945. An atmosphere of anti-German hysteria pervaded Czechoslovakia in the immediate post-war era; Etta remarked how on outings she could not speak German for fear of being lynched. ${ }^{165}$ However, as Etta wrote to her mother, the crucial thing was to be reunited with the family. For Etta, the rupture with Germany was complete: it was no longer a place she considered home. Some Geltungsjuden returned to Germany because this was where their only (gentile) relatives lived ${ }^{166}$, while others, including Etta, left for this very reason.

Arranging Irmgard's emigration epitomized the peak of Etta's resourcefulness, triggered by years of persecution. She organized her mother's emigration, a particularly difficult enterprise, not least because the situation in Berlin was so chaotic. Etta went to Berlin twice to co-ordinate the return of Theresienstadt survivors. The first time she saw her mother she realized she had been assaulted. Irmgard was now just another wounded, humiliated and malnourished Berlin woman: the experience of sexual violence erased all vestiges of her former patrician life. Etta used her mother's Dutch birth certificate and her Theresienstadt connections to get her out of the war-torn capital: she registered Irmgard as a former Dutch prisoner and brought her to Terezín in August 1945. ${ }^{167}$ Both women then accompanied a transport of Jewish orphans to Windermere in the Lake District. ${ }^{168}$ 
In October 1945, Irmgard moved to London and stayed there until the late 1960s, long after her daughters left. Ulla moved to Los Angeles, Etta to New York and Judith to DC. Etta could not find her way in England: she found the country isolating and antisemitic, and she also found it hard to reintegrate into the 'normal' world. ${ }^{169}$ After the community experience of Theresienstadt, which continued for years in the form of letters spread across continents and names in her address books (some people stayed friends for her entire life), Etta was lonely. Irmgard lived very simply, working menial jobs, never complaining. Eventually, when her eyesight and arthritis grew too bad - she turned 70 in 1959 - she moved in with Judith. Judith studied at the London School of Economics, where she fell in love with an American economist and moved with him to Washington, D.C.

Today, there is no one left carrying the surname Veit Simon. Harro's son Hanno changed his surname after his adoption by Harriet's second husband; he and his son are the last of the family in Great Britain. Other descendants live in Chile, Sweden and the United States. Harro converted to Catholicism, remarried and had two sons. When Hanno visited in the 1970s, his father, who had become a Pinochet supporter, suggested they not mention the fact that he was a Jewish divorcé. Ulla divorced and became an artist in the Californian Arroyo Grande. When she was in her 80s, her old boyfriend Hietze Friedensohn found her. They spent their last three years living happily between Israel and California.

Etta married a friend of her siblings, the widowed Chicago physician Erwin Japha; she became mother to his two children, and had another daughter, Irene, named after her Berlin childhood friend. In 1971, her husband died and Etta moved near Ulla. Even though she lived to 91, she never gave testimony about her persecution; unlike most survivors in the United States, she was not interviewed as part of any of the large Holocaust oral-history collections. When she occasionally talked about her wartime years, she would carefully select her topics and refused to answer other questions. We learn of her boyfriend, or taking care of the little Mirjam Smuk, only from other sources. She passed away in Seattle in 2009.

\section{Conclusion: Biedermeier secretary desk in Seattle}

The Veit Simon family's Biedermeier furniture - brought by Irmgard to London and later to the United States - is spread between a D.C. suburb, Manhattan's Upper East Side, New Rochelle and Seattle. The still magnificent pieces are witnesses of the bygone stature of the once eminent Berlin Jewish family, of class that is irretrievably gone. ${ }^{170}$ The transnationality caused by Nazi persecution and war-time rifts has been fading over the years, giving way to the Americans, British and Chileans - very different people connected by letters in German, a language they cannot read, and by relatives who are nearly all dead. Only 'little' Judith remains; she connects the story to its origins, to Berlin and German history. Like many other expelled German Jews, as an old woman Judith reconnected with her native city, wooed by post-war Berliners who wished to atone. The family restituted Katharinenhof ${ }^{171}$ and sold the house to a group of Berlin leftists who again use it as weekend house. Theirs is, understandably, a different history: of two young women Jewish gardeners, who built a little utopia in the March of Brandenburg. ${ }^{172}$

But Katharinenhof is, really, one of the many ends of this piece of transnational history, a ball of yarn: the thread leads us to the Amsterdam Jewish Council, a Wilhelmine career diplomat, and a Nazi general state attorney; to Quakers aiding Jews in hiding and to the painters' workshop in Theresienstadt; to the pulmonologist František Löwit hoping 
to remarry his wife after the war, and to Fritz Lerner's 90-year-old niece in Haifa, upset to learn that her beloved and married uncle had a German lover. This ball of yarn is all of this at once: interesting and anecdotal, it shows the interconnected, simultaneous and transnational nature of the Holocaust.

Nazi persecution turned wealthy Jews into victims, stripping them of their class identity in the process. Paying attention to the impoverishment across socio-economic planes allows for a deeper understanding of the victims; property defines who we are, our taste, and provides the safety of home - issues beyond simple economic capital. Moreover, the Veit Simon history reminds us how much wealth, even declining, enabled the victims to live for a long time in a protective bubble. As long as the family stayed at home, they were able to hold off some aspects of the persecution. But, eventually, the forced emigration and the Holocaust brought people to the ground, both economically and socially. When Ruth contracted tuberculosis, the disease, associated with poverty, was a powerful marker of the family's descent. After the war, we find the mother employed in manual labour. Both Irmgard and Etta were able to fit into their new worlds. Class identity, especially for women, can be easily stripped, and is defined by the new country and work. ${ }^{173}$ But women's class also leaves particular imprints, shaping a habitus ${ }^{174}$, as was the case with Etta's survival.

We started with Micòl Finzi-Contini, portrayed as beautiful, enigmatic, not very practical and ultimately lost. But perhaps rather than Micòl it was Etta Veit Simon, whose agency and resourcefulness were brought about by the persecution, and who changed in the process, who puts a face to the experience of the formerly wealthy during the Holocaust. After the 'adventures' of the war years, Etta lived a quiet life. The Holocaust was far too adventurous, for any story - and for any life.

\section{Notes}

1. That is, beyond memory studies. See, among others: Dreyfus and Stoetzler, "Holocaust Memory in the Twenty-First Century," 69-78.

2. Isabel Hofmeyr in "AHR Conversations: on Transnational History, C. A. Bayly, Sven Beckert, Matthew Connelly, Isabel Hofmeyr, Wendy Kozol and Patricia Seed," 1444; see also Jenkins, "Transnationalism and German History" and Jarausch, "Reflections on Transnational History," January 2006, H-German Forum.

3. See, among others: Lahusen, "Harbin and Manchuria;" Grossmann, "Remapping Relief and Rescue," 61-79; and Goda, Jewish Histories of the Holocaust; Heim, "Widersprüchliche Loyalitäten," 237-52.

4. For reasons of brevity, and to focus on the Holocaust rather than the forced migration, the bulk of the article discusses events in continental Europe.

5. Friedländer, Nazi Germany and the Jews, vol. 2, The Years of Extermination, xxvi.

6. Friedländer, Nazi Germany and the Jews.

7. Important exceptions include Meyer, "Jüdische Mischlinge;" Ofer, "Everyday Life of Jews under Nazi Occupation," 42-69; Miron, "History, Remembrance, and a 'Useful Past", 131-70.

8. Hilberg, The Destruction of European Jews, ch. V.

9. Bourdieu, Distinction.

10. The Garden of the Finzi-Continis, directed by Vittorio de Sica (1970). Giorgio Bassani's original novel ends in 1939, four years before the deportation, which is mentioned only in epilogue. See also Marcus, "De Sica's Garden of the Finzi-Continis," 91-111. Thanks to Steven Carr for drawing our attention to this piece. 
11. See, among others, Grossmann, Jews, Germans, and Allies, ch. 2; Herzog, Brutality and Desire; Mühlhäuser, Eroberungen; Hedgepeth and Saidel, Sexual Violence against Jewish Women during the Holocaust.

12. Milton, "Women and the Holocaust," 297-333; Holmes, "Love, Labour, Loss."

13. Louie, Etta at 80 (unpaginated). When Ron Louie interviewed Etta Japha, his mother-in-law, she implied she did not want to be asked beyond what she was willing to tell, in particular on matters of sexuality in Theresienstadt. Ron Louie to X, 20 May 2014, Seattle.

14. See also Halberstam in "Forum Cultural History and the Holocaust," $63 f$.

15. Among others: Strassmann, The Strassmanns; de Waal, The Hare with Amber Eyes; Erpenbeck, Heimsuchung; Wildman, Paper Love.

16. Etta Japha's reparation file, 76079, M 4 LL (all three reparation files are at Reparation Office Berlin); Hermann Veit Simon, "Address to a Family Society Meeting in Berlin," 13 August 1908, Seattle papers (= papers of Etta Japha, kept at her daughter's, Irene Japha); Veit Simon family papers, Leo Baeck Institute (LBI), AR 4015.

17. Hermann Veit Simon, "Address;" "Generalschutzprivileg," 12 March 1764, John Veit Wilson collection, Jewish Museum Berlin. Henriette was herself a descendant of a prominent Berlin Jewish family and also a former niece by marriage of Dorothea Mendelsohn-Veit-Schlegel.

18. We use first names for members of the Veit Simon family throughout not as a statement of familiarity, but rather for pragmatic reasons to differentiate.

19. Heinrich's reparation file (73837), 8f LL.

20. Within the Foreign Office, the consular ranks were considered less prestigious and predominantly middle-class as opposed to diplomatic service.

21. Heinrich' reparation file, M8.

22. Judith's affidavit from 9 March 1955, Judith Klein's reparation file (274233), M 5.

23. On German Judaism in the Weimar Republic, see Brenner, The Renaissance of Jewish Culture in Weimar Germany.

24. The resplendent dinner invites speak to this point; Seattle papers; statement of Richard Calé, reparation file Etta, p. B 33; statement of Marie-Luise Brickwell-Graeber, 1 September 1953, and Adolf Kraetzer, 31 August 1953, reparation file Heinrich, M12.

25. Adreßbuch Berlin 1933 (Berlin: August Scherl, 1932), 5388; Warhaftig, Deutsche jüdische Architekten vor und nach 1933 - Das Lexikon, $91 \mathrm{ff}$.

26. Statement of Richard Calé, 24 October 1956, reparation file Etta, B33.

27. Claudia Keller, "Juristen ohne Recht," Tagesspiegel, 30 November 2007.

28. In the 1920s, Heinrich lent Käthe 61,000 Mark to keep the premises going, half of which was not paid back when Katharinenhof was sold in 1938. Heinrich's reparation file, 73837, D 3, Irmgard to Käthe, 21 August 1942.

29. Doi, "Through Grandmother's Eyes," 49.

30. Barkai, Vom Boykott zur "Entjudung;" Ahlheim, "Deutsche, kauft nicht bei Juden!"

31. Hans Benfey to Graeber-Brickwell, 16 February 1959, reparation file Heinrich, D15.

32. Bajohr, "Aryanisation" in Hamburg.

33. Anna Hájkovás Skype interview of John Veit-Wilson, December 2012.

34. Kaplan, Between Dignity and Despair, 140f. See also Eggert, "Dr Betty Warburg," http:// stolpersteine-hamburg.de/index.php?MAIN_ID=7\&BIO_ID=929 (Accessed on June 4, 2016).

35. Kaelber, "Jewish Children as Victims of 'Euthanasia' in Nazi Germany."

36. See also Kwiet, "Without Neighbours: Daily Life in Judenhäuser," 117-48.

37. Irmgard was co-owner of the property; Heinrich reparation file, p. M 50. In the late 1930s, only Gisela was publicly named.

38. On Geltungsjuden, see von der Heydt, "'Wer fährt denn gerne mit dem Judenstern in der Straßenbahn?", 65-80; on mixed marriages and Mischlinge in general, see Meyer, "Jüdische Mischlinge."

39. Jüdisches Museum Berlin, ed., Heimat und Exil: Emigration der deutschen Juden nach 1933.

40. See also Kaplan, Between Dignity and Despair, 141f.

41. Dreyfus-Armand, "Les Enfants, ces oubliés de la diaspora républicaine espagnole," 36f. 
42. Family history as collected by John Veit Wilson (John Veit Wilson's personal papers), 2. In 1946, Harriet married Canadian-born Arthur Wilson and in 1965, founded the Child Poverty Action Group.

43. Email Alexander Zahoransky, archive of the University of Freiburg, to X, 12 December 2014.

44. Maria von der Heydt's interview of Judith Klein, 19 June 2012, Berlin.

45. Kuhfuss-Wickenheiser, Die Reimann-Schule in Berlin und London 1902-1943.

46. Löwe, Die bunte Schüssel: Ein jüdisches Kinderbuch zum Lesen und Malen.

47. Ismar Elbogen to Adolph Oko, 25 July 1938, LBI, Elbogen papers. We should like to thank Michael Ehmann for drawing our attention to this document.

48. Schwoch, Berliner jüdische Kassenärzte und ihr Schicksal im Nationalsozialismus, 827.

49. Doi, “Through Grandmother's Eyes," 26.

50. Louie, Etta at 80.

51. Rolf's police registration file, Municipal Archive Amsterdam, 5225, inv. nr. 4210.

52. Kunstamt Schöneberg, Orte des Erinnerns: Jüdisches Alltagsleben im Bayerischen Vierte, 84 f; Etta's statement, 30 October 1956, and statement of Helga Frenkel-Brinitzer, 29 October 1956, Etta’s reparation file, B31f.

53. Doi, "Through Grandmother's Eyes," 24.

54. Aurich and Santarius, Die Geschichte des Katharinenhofes in Gransee, 8f; Verordnung über die Anmeldung des Vermögens von Juden, 26 April 1938, Reichsgesetzblatt, I 414.

55. Fifth regulation regarding the National Citizen Act, 27 September 1938, Reichsgesetzblatt, I, 1403; list of former lawyers admitted as "Konsulenten" for Berlin, 15 September 1939, Landesarchiv Berlin, Rep. 68 Acc. 3209, 68.

56. Ladwig-Winters, Anwalt ohne Recht: Das Schicksal jüdischer Rechtsanwälte in Berlin nach 1933, 71f.

57. Brickwell-Graeber, Erläuterungen, 15 January 1952, reparation file Heinrich, D 2f.

58. Ziegler, "Die Wertpapierkonfiskation und die Rolle der Banken," 168-70.

59. Irmgard Veit Simon, CV (ca. 1952), reparation file Heinrich, M 8f. See also Steinweis, Kristallnacht 1938.

60. Louie, Etta at 80. The Elbogen correspondence did not bring up Ruth's illness.

61. London, Whitehall and the Jews 1933-1948; Bivins, Contagious Communities, ch. 1.

62. Gilman, Franz Kafka, the Jewish Patient, ch. 4.

63. Ruth to her parents, 20 September 1938, Seattle papers.

64. Heim, Die Verfolgung und Ermordung der europäischen Juden durch das nationalsozialistische Deutschland 1933-1945, vol. 2, Deutsches Reich 1938-August 1939, document nr. 127, 369-70.

65. Schellinger, Oswald, and Hoferer, Deportiert aus Nordrach, 12, fn 16.

66. Schellinger, Oswald, and Hoferer, 16; more generally on the Reich Association and welfare see Meyer, Tödliche Gratwanderung, 106-12.

67. Ruth to parents, 6 August 1940, Seattle papers.

68. Kaplan, Between Dignity and Despair, 34.

69. Dring and Ehmann, "Albert Fraenkel und das Tuberkulosekrankenhaus Rohrbach," 241-94.

70. Ruth to her parents, 16 July 1940, Seattle papers.

71. Louie, Etta at 80.

72. Etta to parents, 26 July 1940, Seattle papers.

73. Ruth to her parents, 16 July 1940, Seattle papers.

74. Louie, Etta at 80.

75. Helmuth Gabriel's personal file (Reich Ministry of Justice), CV, German Federal Archive (Lichterfelde) (= BA), R3001, 56769.

76. Certificate of conduct, (1926), BA, R3001, 56764.

77. Doi, “Through Grandmother's Eyes," 9.

78. Niermann, Die Durchsetzung politischer und politisierter Strafjustiz im Dritten Reich, 150; Wachsmann, Hitler's Prisons: Legal Terror in Nazi Germany, 117.

79. Helmuth Gabriel's personal file, income statement for 1937.

80. Sicherheitsdienst to K.H. Frank, 6 October 1939, National Archive Prague (=NA), 109.

81. Gruchmann, Justiz im Dritten Reich 1933-1940, 287. 
82. Gabriel's police registration, National Archive Prague.

83. Werner Langbehn lived at 15 Masná, a modern functionalist building in the city centre. Davidson, Perfect Nazi, 212.

84. Thierack to KH Frank, 23 February 1943, NA, 109.

85. Czechoslovak Ministry of Interior to the Czech Liaison of the War Crimes Branch, Dr Hrbek, 2 March 1946, NA Prague, 316-1-2.

86. Case of son and father Josef Flígr from Dobruška, both executed on 1 September 1944, Security Services Archive, Prague (ABS), 141-99-5.

87. Poelchau, "Die Katze darf leben," 155-9.

88. Email Andreas Herbst, Memorial of German Resistance, to X, 1 December 2014.

89. Irmgard confirmation, 12 February 1952, Etta's reparation file M 4; Louie, Etta at 80. On forced labour in Berlin, see Glauning, "Alltag Zwangsarbeit 1938-1945."

90. Von der Heydt, "Straßenbahn," 74.

91. The plan was actually feasible; this was the flight route for hundreds of escapees: Meyer and Meinen, Verfolgt von Land $z$ u Land.

92. For a critical assessment, see Schrafstetter, Flucht und Versteck.

93. Meyer and Meinen, Verfolgt von Land zu Land, 130 and 306, fn. 6.

94. Louie, Etta at 80.

95. "Uncle Udotimay" to Irmgard, 24 May 1942, Seattle papers, 3749.

96. Poelchau, "Katze darf leben."

97. Statement of Adolf Kraetzer, 31 August 1953, Heinrich's reparation file.

98. Anonymous to Irmgard, no date [end of May 1942], Seattle papers.

99. Louie, Etta at 80.

100. See Angrick and Klein, The "Final Solution" in Riga.

101. On women's better coping abilities during the Holocaust, see the Milton, "Women and the Holocaust."

102. Etta to Irmgard, 22 May 1942, Seattle papers.

103. Friedländer, Nazi Germany and the Jews, vol. 2, The Years of Extermination, 8f, 438-43; see also Goldberg, "The Victim's Voice in History and Melodramatic Esthetics," 220-37.

104. See also the interview of Marie Deimlová-Ch., Jewish Museum Prague, Vzpomínky, nr. 532.

105. Etta’s obituary for Baeck, Seattle Papers. On the Große Hamburger, see Jah, Die Deportation der Juden aus Berlin.

106. Similarly, at the beginning of June 1942, after the Jewish resistance group Baum attacked the "Soviet Paradise" propaganda exhibition, 154 hostages were killed in Sachsenhausen, their (largely young) wives deported to Theresienstadt on the transport of 5 June 1942. Jah, Die Deportationen, 292-5. The change of deportation guidelines for single Geltungsjuden was announced only on 7 June 1942, and took effect even later.

107. Damwerth, Arnold Munter: Der Jahrhundertzeuge, 84.

108. The cat comes up even in the Theresienstadt postcards.

109. Diary of Victor Klemperer, entries for 15 May and 18 May 1942, in Klemperer, Ich will Zeugnis ablegen bis zum letzten.

110. Poelchau, "Die Katze darf leben."

111. Jakob and van der Voort, Anne Frank war nicht allein; Dittrich and Wojak, "Geliebte Kinder ..."

112. Barnouw, Anne Frank voor Beginners en Gevorderden, passim.

113. Rolf's police registration.

114. Schwarzschild, Niet lezen alstublieft/Nicht lesen Bitte, entry for 12 June 1941; for Schoorl, see Hijink, "Das Internierungs- und Durchgangslager Schoorl," 106f. The other released prisoner was Günther Goldbarth, who lied about being a Mischling: Goldbarth, "Lives Lived: Guenther Goldbarth, 89," Globe and Mail, 8 July 2013.

115. Houwink ten Cate, "Heydrich's Security Police and the Amsterdam Jewish Council (February 1941-October 1942)," 381-93; Michman, The Emergence of Jewish Ghettos during the Holocaust, ch. 9.

116. Houwink ten Cate, "Het jongere deel: Demografische en sociale kenmerken van het jodendom in Nederland tijdens de vervolging," 9-66. 
117. Schwarzschild, entry for 11 October 1942.

118. For Nahalal, see Berg, "Zionism's Gender," 135-65.

119. In Cologne, Rolf belonged to the Schwarzes Fähnlein, a right-wing Jewish youth organization. Dieter Corbach's interview of Gerhard Braun, 12 October 1985, NS Dokumentationszentrum Cologne. Thanks to Nina Matuszewski for sending us the source.

120. Wenck, Zwischen Menschenhandel und "Endlösung;" Wasserstein, The Ambiguity of Virtue.

121. Sabine Simon-Smuk and Rolf Simon's file card from the Jewish Council registry, Red Cross, The Hague. Thanks to Raymond Schütz for copies.

122. Anna Hájkovás phone interview of Mirjam Smuk-Weitzner (Haarlem), 12 December 2012.

123. Hájková, "Die Juden aus den Niederlanden in Theresienstadt," 135-201, 145-9.

124. Rolf to Irmgard, 24 June 1943, cited in Irmgard's letter to Etta; Rolf to Irmgard, 14 July 1943, copied in Irmgard's letter to Etta, 26 August 1943.

125. Irmgard to Etta, 2 August 1943 citing Rolf to Irmgard, 24 June 1943, Seattle papers (In this letter Irmgard reacted to the news of Ruth's death.)

126. Hájková, "Das Polizeiliche Durchgangslager Westerbork," 217-48.

127. Entry for 16 November 1943, Mechanicus, In Depot; Dagboek uit Westerbork, 202.

128. Neither the International Tracing Service of the Red Cross in Bad Arolsen nor the archive of the Oświęcim Memorial have any further records of her.

129. On 14 January 1944, he was registered as sick in the Birkenau male camp BIIa. Email of Krystyna Lesniak, Oświęcim Memorial, to X, 19 November 2014.

130. Theresienstadt was a ghetto rather than a concentration camp. See Klein, "Theresienstadt: Ghetto oder Konzentrationslager?”, 111-23; White, “Terezín," 179-84; Hájková, “The Last Ghetto," 15.

131. Hájková, "Mutmaßungen über deutsche Juden," 179-98.

132. Anna Hájkovás interview of Martin Kluger, Berlin, 29 December 2014, recalling Kluger’s conversation with Etta from 1975.

133. Medical certificate B, 20 December 1954, reparation file Etta, B8.

134. Hájková, “The Last Ghetto," ch. 4 (Medicine and Illness).

135. See also Eliška K., Vzpomínky, ŽMP.

136. Hájková, “The Last Ghetto," ch. 3 (Food and Hunger).

137. On Nadolny's career as a diplomat, see Jenkins, "Fritz Fischer's 'Programme for Revolution," 397-417.

138. Sharon Rivo's (National Center for Jewish Film) interview of Etta Japha, 7 April 1985, Carol Japha papers. The National Center for Jewish Film lost the interview tape; this is the only surviving copy of the interview.

139. Adler, Theresienstadt 1941-1945, 696.

140. Lucy Mandelstam, ME 1472, LBI; memoir of Jiř́ Borský, 66, Beit Terezin Archive; Anna Hájkovás interview of Doris Meyer Stern, 10 April 2001 in Beit Yitshak, Israel.

141. In the 1950s, Etta related to her adoptive daughter that in Theresienstadt she was a chain smoker. Carol Japha to X, 12 May 2014.

142. Rivo interview of Etta Japha.

143. Ilse Windholz-Lerner's entry in the database of the Oświęcim Memorial.

144. Rolf's Red Cross wire to Ulla, 10 July 1943, Arroyo Grande papers.

145. Anna Hájkovás phone interview Mirjam Smuk-Weitzner, November 2012.

146. Manes, Als ob's ein Leben wär: Tatsachenbericht. Theresienstadt 1942-1944, 329f.

147. Anna Hájkovás correspondence with Daniel Dražan (Löwit's grand-nephew), March 2013.

148. Hájková, "The Last Ghetto," ch. 4 (Medicine and Illness).

149. Statistics of Irma Goldmann, Yad Vashem Archives, O64, 50.

150. Kraus, "Boj proti tuberkulose v koncentračnich táborech," 131-3.

151. Irmgard to Etta, 2 August 1943.

152. Irmgard to "Fräulein Käthe Veit Simon," 21 August 1942, reparation file Heinrich, D 3.

153. Doi, “Through Grandmother's Eyes," 50; Irmgard's letters to Etta in Theresienstadt.

154. Irmgard to Etta, 26 September 1943 and August/September 1944. 
155. Schieb, Nachricht von Chotzen, 122-4. See also Maria von der Heydt, "Sobald ich schreiben kann, wirst du von mir hören," 162-203.

156. Pieken and Kruse, Das Haushaltsbuch der Elsa Chotzen, ch. 7 ("1943/1944: Pakete nach Theresienstadt").

157. Brickwell-Graeber to the Reparation office, 27 January 1959, A 24; Irmgard's application for pension and memorandum from 30 November 1955, D 14, both reparation file Heinrich.

158. The literature on Berliners helping the Jews in hiding is extensive, including: Grossmann, Die unbesungenen Helden; Kosmala and Schoppmann, Uberleben im Untergrund; Harpprecht, Harald Poelchau; Rudolf, Hilfe beim Sprung ins Nichts; Voigt, "Grüße von 'Ferdinand," 104-16; Lutjens, "Jews in Hiding in Nazi Berlin, 1941-1945."

159. See also Gailus, Mir aber zerriss es das Herz, 11 and passim.

160. Jacobson, Die Judenbürgerbücher der Stadt Berlin, 1809-1851, 711.

161. Cornelia Liebold, Bautzen Memorial, to X, 16 June 2014 (entry to the list of the dead and entry to Journal).

162. Maria von der Heydt's interview of Judith Klein; Doi, “Through Grandmother's Eyes," 36. Irmgard became infected with HPV and developed cervical cancer. Gaby Levine to AH, May 2014.

163. Grossmann, Jews, Germans, and Allies, ch. 2.

164. Etta to Irmgard, 30 June 1945, Seattle papers.

165. Etta to Irmgard, 11 July 1945, Seattle papers; on the anti-German panic, see Frommer, National Cleansing.

166. Von der Heydt, "Sobald ich schreiben kann," 186-8.

167. Irmgard's Theresienstadt documentation, Seattle papers.

168. Sworn declaration Etta Japha, 8 January 1954, Etta Japha’s reparation file, C16; on Windermere, see also Gilbert, Boys: Triumph over Adversity, ch. 13 (“Windermere”); email Trevor Avery to $\mathrm{X}, 3$ June 2016.

169. Louie, Etta at 80; Anna Hájkovás interview of Martin Kluger.

170. For approach of material culture history see among others, Adamson and Riello, "Global Objects: Contention and Entanglement," 177-93.

171. Aurich and Santarius, Die Geschichte des Katharinenhofes, 26.

172. Aurich and Santarius, Die Geschichte des Katharinenhofes.

173. Rose Holmes made a similar point on the bourgeois women refugees who were only allowed to the UK to work in domestic service, Holmes, "Love, Labour, Loss."

174. Steedman, Landscape for a Good Woman.

\section{Acknowledgements}

We are deeply grateful to the Veit Simon descendants for their generous assistance in making papers available, answering questions and being open to the view from outside: Irene Japha, Ron Louie, Mikaela Louie, Judith and Tom Klein, Carol Japha, Gaby Levine, Susie Mackey, Tony and Joan Japha, John Veit Wilson, Michael Weill and Martin Kluger. We gratefully acknowledge the financial assistance of the Warwick Transatlantic Fellowship that enabled Anna Hájkovás research trip across North America. We should like to thank our friends and colleagues: Dana Smith, Stephen Ross and Harvey Day for proof-reading; Laura Schwartz, Atina Grossmann and Robert Fine for sage comments on various drafts; Roberta Bivins, Michael Ehmann, Donna Harsch, Harro Jenß and Hilary Marland for medical advice; Martina Voigt and Barbara Schieb for sharing their unparalleled knowledge on helping networks for Berlin Jews in hiding; and to Alexandra Garbarini and Michael Simonson for counsel of all kinds. We are indebted to Albane Duvillier for drawing and re-drawing the family tree and putting up with one of the authors. Thanks to Michael Berkowitz (UCL) and Johannes Heil's (Hochschule für jüdische Studien Heidelberg) invitations to present this work. We also appreciate the Katharinenhof circle for asking us to present at the house's centenary and Johanna Bussemer's and Hermann Aurich's benevolent input. Finally, great thanks to Jean-Marc Dreyfus for his wise and hands-on interventions, and to the anonymous readers' suggestions that made the piece far superior and saved it from terrors of positivism. The shortcomings that are bound to remain are ours. 


\section{Notes on contributors}

Anna Hájková (PhD, University of Toronto, 2013) is an assistant professor of Modern European Continental History at the University of Warwick. Her manuscript on history of Theresienstadt was awarded both the Irma Rosenberg as well as the Herbert Steiner Prize. She co-edited Alltag in Holocaust (Oldenbourg, 2013). She is working on two projects, a generational history of Central European Communists between 1930 and 1970; second exploring transgressive sexuality among the Holocaust victims.

Maria von der Heydt (Dr. iur., Humboldt University, 1998) is the founding partner of Heinchen Laudien Attorneys. In addition to her work in litigation and insolvency law, she is researching the persecution of Jews and non-Jews in mixed relationships and/or of mixed parentage, focusing on "Geltungsjuden". She is an affiliated member of the Centre for Antisemitism Research at the Technical University Berlin. Her recent publications include "Wer fährt denn gerne mit dem Judenstern in der Straßenbahn?” Die Ambivalenz des “geltungsjüdischen” Alltags zwischen 1941 und 1945, in: Doris Bergen, Andrea Löw, and Anna Hájková, eds., Alltag im Holocaust: Jüdisches Leben im Großdeutschen Reich 1941-1945 (Oldenbourg, 2013).

\section{Bibliography}

"AHR Conversations: on Transnational History: C. A. Bayly, Sven Beckert, Matthew Connelly, Isabel Hofmeyr, Wendy Kozol and Patricia Seed." The American Historical Review 111, no. 5 (December 2006): 1441-1464.

Adamson, Glenn, and Giorgio Riello. "Global Objects: Contention and Entanglement." In Writing the History of the Global: Challenges for the Twenty-First Century, edited by Maxine Berg, 177-193. Oxford: British Academy, 2013.

Adler, H. G. Theresienstadt 1941-1945: Das Antlitz einer Zwangsgemeinschaft. Göttingen: Wallstein, 2005.

Ahlheim, Hannah. "Deutsche, kauft nicht bei Juden!" Antisemitismus und politischer Boykott in Deutschland 1924 bis 1935. Göttingen: Wallstein, 2011.

Angrick, Andrej, and Peter Klein. The "Final Solution" in Riga: Exploitation and Annihilation, 1941-1944. New York, NY: Berghahn, 2009.

Aurich, Hermann, and Tilman Santarius. Die Geschichte des Katharinenhofes in Gransee. Gransee: private press, 2013.

Bajohr, Frank. "Aryanisation" in Hamburg: The Economic Exclusion of Jews and the Confiscation of their Property in Nazi Germany. New York, NY: Berghahn, 2002.

Barkai, Avraham. Vom Boykott zur "Entjudung": Der wirtschaftliche Existenzkampf der Juden im Dritten Reich, 1933-1943. Frankfurt am Main: Fischer, 1988.

Barnouw, David. Anne Frank voor Beginners en Gevorderden. Den Haag: SDU, 1998.

Berg, Gerry. "Zionism's Gender: Hannah Meisel and the Founding of the Agricultural Schools for Young Women." Israel Studies 6, no. 3 (2001): 135-165.

Bivins, Roberta. Contagious Communities: Medicine, Migration, and the NHS in Post War Britain. Oxford: Oxford University Press, 2015.

Bourdieu, Pierre. Distinction: A Social Critique of the Judgement of Taste. Cambridge, MA: Harvard University Press, 1984.

Brenner, Michael. The Renaissance of Jewish Culture in Weimar Germany. New Haven, CT: Yale University Press, 1996.

Damwerth, Ruth. Arnold Munter: Der Jahrhundertzeuge. Berlin: Neues Leben, 1994.

Davidson, Martin. Perfect Nazi: Uncovering My SS Grandfather's Secret Past and how Hitler Seduced a Generation. London: Viking, 2010.

Dittrich, Kathinka, and Irmtrud Wojak, eds. "Geliebte Kinder ..." : Briefe aus dem Amsterdamer Exil in die Neue Welt 1939-1943. Essen: Klartext, 1995.

Doi, Courtney Cleary. “Through Grandmother's Eyes: A Blended History.” MA thesis, North Carolina State University, 2006. 
Dreyfus, Jean Marc, and Marcel Stoetzler. "Holocaust Memory in the Twenty-First Century: Between National Reshaping and Globalisation." European Review of History: Revue européenne d'histoire 18, no. 1 (2011): 69-78.

Dreyfus-Armand, Geneviève. "Les Enfants, ces oubliés de la diaspora républicaine espagnole." In Exils, passages et transitions: chemins d'une recherche sur les marges des républicains espagnols en France: De la Guerre civile à la mort de Franco, edited by Anne Dubet and Stéphanie Urdician, 32-42. Paris: Presses Universitaires Blaise Pascal, 2008.

Dring, Peter, and Ehmann Michael. "Albert Fraenkel und das Tuberkulosekrankenhaus Rohrbach." In Albert Fraenkel: Ein Arztleben in Licht und Schatten, 1864-1938, edited by Peter Drings, Jörg Thierfelder, Bernd Weidmann, and Friedrich Willig. Landsberg: ecomed, 2004.

Eggert, Björn. "Dr Betty Warburg." Accessed June 4, 2016. http://stolpersteine-hamburg.de/index. php?MAIN_ID=7\&BIO_ID=929

Erpenbeck, Jenny. Heimsuchung. Munich: btb, 2010.

Friedländer, Saul. Nazi Germany and the Jews. 2 vols. New York, NY: HarperPerennial, 2006.

Frommer, Benjamin. National Cleansing: Retribution against Nazi Collaborators in Postwar Czechoslovakia. New York, NY: Cambridge University Press, 2005.

Gailus, Manfred. Mir aber zerriss es das Herz: Der stille Widerstand der Elisabeth Schmitz. Göttingen: Vandenhoeck \& Ruprecht, 2012.

Gilbert, Martin. Boys: Triumph over Adversity. London: Phoenix, 1997.

Gilman, Sander. Franz Kafka, the Jewish Patient. New York, NY: Routledge, 1995.

Glauning, Christine (ed.). "Alltag Zwangsarbeit 1938-1945:" Die neue Dauerausstellung im Dokumentationszentrum NS-Zwangsarbeit Berlin-Schöneweide. Berlin: Stiftung Topographie des Terrors, 2013.

Goda, Norman (ed.). Jewish Histories of the Holocaust: New Transnational Approaches. New York, NY: Berghahn, 2014.

Goldbarth, Michael. "Lives Lived: Guenther Goldbarth, 89.” Globe and Mail 8 (July 2013).

Goldberg, Amos. “The Victim's Voice in History and Melodramatic Esthetics." History and Theory 48 , no. 3 (2009): 220-237.

Grossmann, Atina. Jews, Germans, and Allies: Close Encounters in Occupied Germany. Princeton: Princeton University Press, 2007.

Grossmann, Atina. "Remapping Relief and Rescue: Flight, Displacement, and International Aid for Jewish Refugees during World War II.” New German Critique 39, no. 3 (2012): 61-79.

Grossmann, Kurt G. Die unbesungenen Helden: Menschen in Deutschlands dunklen Tagen. Berlin: Arani, 1957.

Gruchmann, Lothar. Justiz im Dritten Reich 1933-1940: Anpassung und Unterwerfung in der Ära Gürtner. Munich: Oldenbourg, 1990.

Hájková, Anna. "Die Juden aus den Niederlanden in Theresienstadt." Theresienstädter Studien und Dokumente (2002): 135-201.

Hájková, Anna. "Das Polizeiliche Durchgangslager Westerbork." In Terror im Westen: Nationalsozialistische Lager in den Niederlanden, Belgien und Luxemburg 1940-1945, edited by Wolfgang Benz and Barbara Distel, 217-248. Berlin: Metropol, 2004.

Hájková, Anna. "Mutmaßungen über deutsche Juden: Alte Menschen aus Deutschland im Theresienstadtädter Ghetto." In Alltag im Holocaust: Jüdisches Leben im Großdeutschen Reich 19411945, edited by Doris Bergen, Andrea Löw and Anna Hájková, 179-198. Munich: Oldenbourg, 2013.

Hájková, Anna. “The Last Ghetto: An Everyday History of Theresienstadt, 1941-1945." Manuscript. Halberstam, Jack. "Forum Cultural History and the Holocaust." German History 31, no. 1 (2013): 61-85.

Harpprecht, Klaus. Harald Poelchau: Ein Leben im Widerstand. Reinbek: Rowohlt, 2004.

Hedgepeth, Sonja, and Rochelle Saidel (eds.). Sexual Violence against Jewish Women during the Holocaust. Hanover, N.H.: University Press of New England, 2010.

Heim, Susanne, ed. Die Verfolgung und Ermordung der europäischen Juden durch das nationalsozialistische Deutschland 1933-1945, vol. 2, Deutsches Reich 1938-August 1939. Munich: Oldenbourg, 2011. 
Heim, Susanne. "Widersprüchliche Loyalitäten: Die Reaktionen internationaler jüdischer Hilfsorganisationen auf die Situation der deutschen Juden.” In Alltag im Holocaust: Jüdisches Leben im Großdeutschen Reich 1941-1945, edited by Andrea Löw, Doris Bergen and Anna Hájková, 237-252. Munich: Oldenbourg, 2013.

Herzog, Dagmar (ed.). Brutality and Desire: War and Sexuality in Europe's Twentieth Century. Basingstoke: Palgrave Macmillan, 2009.

Heydt, Maria von der. “'Sobald ich schreiben kann, wirst du von mir hören:' Johanna Larché-Levy.” Theresienstädter Studien und Dokumente (2006): 162-203.

Heydt, Maria von der. “Wer fährt denn gerne mit dem Judenstern in der Straßenbahn?' Die Ambivalenz des 'geltungsjüdischen' Alltags zwischen 1941 und 1945." In Alltag im Holocaust: Jüdisches Leben im Großdeutschen Reich 1941-1945, edited by Andrea Löw, Doris Bergen, and Anna Hájková, 65-80. Munich: Oldenbourg, 2013.

Hijink, Roel. "Das Internierungs- und Durchgangslager Schoorl." In Terror im Westen: Nationalsozialistische Lager in den Niederlanden, Belgien und Luxemburg 1940-1945, edited by Wolfgang Benz and Barbara Distel, 101-115. Berlin: Metropol, 2004.

Hilberg, Raul. “The Destruction of European Jews, 3 vols." New Haven: Yale University Press 2003 (1961).

Holmes, Rose. "Love, Labour, Loss: Women, Refugees and the 'Servant Crisis' in Interwar Britain." Talk, University of Warwick 21 (May 2015).

Houwink ten Cate, Johannes. "Het jongere deel: Demografische en sociale kenmerken van het jodendom in Nederland tijdens de vervolging." Oorlogsdocumentatie 1 (1989): 9-66.

Houwink ten Cate, Johannes. "Heydrich's Security Police and the Amsterdam Jewish Council (February 1941-October 1942)." In Dutch Jewish History, vol. 3, edited by Joseph Michman, 381-393. Assen/Maastricht: Van Gorcum, 1993.

Jacobson, Jacob. Die Judenbürgerbücher der Stadt Berlin, 1809-1851. Berlin: de Gruyter, 1962.

Jah, Akim. Die Deportation der Juden aus Berlin: Die nationalsozialistische Vernichtungspolitik und das Sammellager Große Hamburger Straße. Berlin: bebra, 2013.

Jakob, Volker, and Annett van der Voort. Anne Frank war nicht allein: Lebensgeschichten deutscher Juden in den Niederlanden. Berlin and Bonn: Dietz, 1995.

Jarausch, Konrad. 2006. "Reflections on Transnational History." H-German Forum, January 23. http://h-net.msu.edu/cgi-bin/logbrowse.pl?trx=vx\&list=H-german\&month=0601\&week=d\&ms $\mathrm{g}=\mathrm{fz} 4$ or79bUjZXO9rM/LT0ZQ\&user $=\& \mathrm{pw}=$

Jenkins, Jennifer. “Transnationalism and German History." H-German Forum, January 23, 2006. http://h-net.msu.edu/cgi-bin/logbrowse.pl?trx=vx\&list=H-german\&month=0601\&week=d\&ms $\mathrm{g}=\mathrm{jdQ} 5 \mathrm{FjF3i2OWwWSkGlTt} / \mathrm{w} \& u$ ser $=\& \mathrm{pw}=$

Jenkins, Jennifer. "Fritz Fischer's 'Programme for Revolution': Implications for a Global History of Germany in the First World War." Journal of Contemporary History 48 (2013): 397-417.

Jüdisches Museum Berlin, ed. Heimat und Exil: Emigration der deutschen Juden nach 1933. Frankfurt/ Main: Jüdischer Verlag, 2006.

Kaelber, Lutz. "Jewish Children as Victims of 'Euthanasia' in Nazi Germany." Paper, Lessons and Legacies, Boca Raton, FL, October 30-November 2, 2014.

Kaplan, Marion. Between Dignity and Despair: Jewish Life in Nazi Germany. New York, NY: Oxford University Press, 1998.

Keller, Claudia. “Juristen ohne Recht.” Tagesspiegel 30 (November 2007).

Klein, Peter. "Theresienstadt: Ghetto oder Konzentrationslager?” Theresienstädter Studien und Dokumente (2005): 111-123.

Klemperer, Viktor. Ich will Zeugnis ablegen bis zum letzten: Tagebücher 1933-1945. Edited by Walter Nowojski. Berlin: Aufbau, 1996.

Kosmala, Beate, and Claudia Schoppmann (eds.). Überleben im Untergrund: Hilfe für Juden in Deutschland, 1941-1945. Berlin: Metropol, 2002.

Kraus, Evžen. "Boj proti tuberkulose v koncentračnich táborech." Masarykova liga proti tuberkulose 27, no. 8 (1946): 131-133.

Kuhfuss-Wickenheiser, Swantje. Die Reimann-Schule in Berlin und London 1902-1943. Herzogenrath: Shaker, 2009. 
Schöneberg, Kunstamt (ed.). Orte des Erinnerns: Jüdisches Alltagsleben im Bayerischen Viertel. Berlin: Hentrich und Hentrich, 1994.

Kwiet, Konrad. "Without Neighbours: Daily Life in Judenhäuser." In Jewish Life in Nazi Germany: Dilemmas and Responses, edited by Francis R Nicosia and David Scrace, 117-148. New York, NY: Berghahn, 2010.

Ladwig-Winters, Simone. Anwalt ohne Recht: Das Schicksal jüdischer Rechtsanwälte in Berlin nach 1933. Berlin: bebra, 2008.

Lahusen, Thomas, ed. "Harbin and Manchuria: Place, Space, and Identity." South Atlantic Quarterly 99, no. 1 (2000).

London, Louise. Whitehall and the Jews 1933-1948: British Immigration Policy, Jewish Refugees and the Holocaust. Cambridge: Cambridge University Press, 2001.

Louie, Ron. Etta at 80. Seattle, WA: family press, 1998.

Löwe, Erwin (ed.). Die bunte Schüssel: Ein jüdisches Kinderbuch zum Lesen und Malen. Berlin: Erwin Löwe, 1936.

Lutjens, Richard. Jews in Hiding in Nazi Berlin, 1941-1945. PhD Diss.: Northwestern University, 2012.

Manes, Philipp. Als ob’s ein Leben wär: Tatsachenbericht. Theresienstadt 1942-1944. Berlin: Ullstein, 2005.

Marcus, Millicent. "De Sica's Garden of the Finzi-Continis: An Escapist Paradise Lost." In Filmmaking by the Book: Italian Cinema and Literary Adaptation, 91-111. Baltimore, MD: Johns Hopkins University Press, 1993.

Mechanicus, Philipp. In Depot: Dagboek uit Westerbork. Amsterdam: AL, 1978.

Meyer, Ahlrich, and Insa Meinen. Verfolgt von Land zu Land: Jüdische Flüchtlinge in Westeuropa 1938-1944. Paderborn: Schöningh, 2013.

Meyer, Beate. "Jüdische Mischlinge": Rassenpolitik und Verfolgungserfahrung 1933-1945. Hamburg: Dölling und Galitz, 1999.

Meyer, Beate. Tödliche Gratwanderung: Die Reichsvereinigung der Juden in Deutschland zwischen Hoffnung, Zwang, Selbstbehauptung und Verstrickung (1939-1945). Göttingen: Wallstein, 2011.

Michman, Dan. The Emergence of Jewish Ghettos during the Holocaust. Cambridge: Cambridge University Press, 2011.

Milton, Sibyl. "Women and the Holocaust: The Case of German and German-Jewish Women." In When Biology Became Destiny: Women in Weimar and Nazi Germany, edited by R Bridenthal, A Grossmann and M Kaplan, 297-333. New York, NY: Monthly Review Press, 1984.

Miron, Guy. "History, Remembrance, and a 'Useful Past' in the Public Thought of Hungarian Jewry, 1938-1939.” Yad Vashem Studies 32 (2004): 131-170.

Mühlhäuser, Regina. Eroberungen: Sexuelle Gewalttaten und intime Beziehungen deutscher Soldaten in der Sowjetunion 1941-1945. Hamburg: Hamburger Edition, 2010.

Niermann, Hans-Eckhard. Die Durchsetzung politischer und politisierter Strafjustiz im Dritten Reich: Ihre Entwicklung aufgezeigt am Beispiel des OLG-Bezirks Hamm 1933-1945. Düsseldorf: Landesjustizministerium, 1995.

Ofer, Dalia. "Everyday Life of Jews under Nazi Occupation: Methodological Issues." Holocaust and Genocide Studies 9, no. 1 (1995): 42-69.

Pieken, Gorch, and Cornelia Kruse. Das Haushaltsbuch der Elsa Chotzen: Schicksal einer jüdischen Familie in Berlin 1937-1946. Berlin: Nicolai, 2008.

Poelchau, Harald. "Die Katze darf leben." In Die Ordnung der Bedrängten - Erinnerungen des Gefängnisseelsorgers und Sozialpfarrers (1903-1972), edited by Heinrich Poelchau, 155-159. Teetz: Hentrich und Hentrich, 2004.

Rudolf, Katrin. Hilfe beim Sprung ins Nichts: Franz Kaufmann und die Rettung von Juden und "nichtarischen" Christen. Berlin: Metropol, 2005.

Schellinger, Uwe, Rolf Oswald, and Egbert Hoferer. Deportiert aus Nordrach. Nordrach: Historische Gruppe für Mittelbaden, 2009.

Schieb, Barbara. Nachricht von Chotzen: "Wer immer hofft, stirbt singend". Berlin: Hentrich, 2002.

Schrafstetter, Susanna. Flucht und Versteck: Untergetauchte Juden in München - Verfolgungserfahrung und Nachkriegsalltag. Göttingen: Wallstein, 2015. 
Schwarzschild, Ellen. Niet lezen alstublieft/Nicht lesen Bitte: Onuitwisbare herinneringen (1933-1943). Amstelveen: private press, 1999.

Schwoch, Rebecca (ed.). Berliner jüdische Kassenärzte und ihr Schicksal im Nationalsozialismus. Berlin: Hentrich und Hentrich, 2009.

Steedman, Carolyn. Landscape for a Good Woman: A Story of Two Lives. London: Virago, 1986.

Steinweis, Alan. Kristallnacht 1938. Cambridge, MA: Harvard University Press, 2009.

Strassmann, W. Paul. The Strassmanns: Science, Politics and Migration in Turbulent Times (1793-1993). New York, NY: Berghahn, 2008.

The Garden of the Finzi-Continis. directed by Vittorio de Sica. Italy: Documento Film, 1970.

Voigt, Martina. "Grüße von 'Ferdinand': Elisabeth Abeggs vielfältige Hilfe für Verfolgte”. In Sie blieben unsichtbar. Zeugnisse aus den Jahren 1941 bis 1945, , edited by Beate Kosmala and Claudia Schoppmann, 104-116. Berlin: GDW, 2006.

de Waal, Edmund. The Hare with Amber Eyes: A Family's Century of Art and Loss. New York, NY: Farrar, Straus and Giroux, 2010.

Wachsmann, Nikolaus. Hitler's Prisons: Legal Terror in Nazi Germany. New Haven, CT: Yale University Press, 2004.

Warhaftig, Myra. Deutsche jüdische Architekten vor und nach 1933 - Das Lexikon. Berlin: Dietrich Reimer, 2005.

Wasserstein, Bernard. The Ambiguity of Virtue: Gertrude van Tijn and the Fate of the Dutch Jews. Cambridge, MA: Harvard University Press, 2014.

Wenck, Alexandra Wenck. Zwischen Menschenhandel und "Endlösung": das Konzentrationslager Bergen-Belsen. Paderborn: Schöningh, 2000.

White, Joseph. “Terezín." In The United States Holocaust Memorial Museum Encyclopedia of Camps and Ghettos, 1933-1945, edited by Geoffrey Megargee, 179-184. Bloomington: Indiana University Press and USHMM, 2009.

Wildman, Sarah. Paper Love: Searching for the Girl My Grandfather Left Behind. New York, NY: Riverbed Books, 2014.

Ziegler, Dieter. “Die Wertpapierkonfiskation und die Rolle der Banken." In Vor der Vernichtung: Die staatliche Enteignung der Juden im Nationalsozialismus, edited by Katharina Stengel, 161-181. Frankfurt/Main: Campus, 2007. 